\title{
INTERPRETATION OF VISUAL STIMULUS AS A STRATEGY FOR DEVELOPING THE CRITICAL AND CREATIVE THINKING
}

\section{[INTERPRETACIA VIZUALNEHO PODNETU AKO STRATEGIA ROZVOJA KRITICKEHO A TVORIVEHO MYSLENIA]}

\author{
Adriana Recka
}

doi: 10.18355/PG.2019.8.1.16

\begin{abstract}
The paper is devoted to the issue of university preparation of future teachers of fine arts through the interpretation of visual stimuli as one of the strategies for developing their critical and creative thinking. The author examines the problem in relation to the objectives of the project supported by the Research and Development Agency under contract no. APVV-15-0368 in the context of current teaching practice requirements for developing critical thinking and creativity.
\end{abstract}

\section{Key words}

higher education teacher of fine arts, interpretation, visual stimulus, critical thinking, creativity

\section{Anotácia}

Príspevok je venovaný problematike vysokoškolskej prípravy budúcich učitel'ov výtvarného umenia formou interpretácie vizuálnych podnetov ako jednej zo stratégií rozvoja ich kritického a tvorivého myslenia. Autorka skúma problém v súvislosti s ciel'mi projektu podporovaného Agentúrou na podporu výskumu a vývoja podl'a zmluvy č. APVV-15-0368 v kontexte súčasných požiadaviek pedagogickej praxe voblasti rozvoja kritického myslenia a kreativity.

\section{Kl'účové slová}

vysokoškolská príprava učitel'a výtvarného umenia, interpretácia, vizuálny podnet, kritické myslenie, tvorivost'

\section{1 Úvod}

Vizuálna gramotnost' definovaná autormi Bristor a Drake (1994) ako "schopnost' porozumiet', interpretovat' a vyhodnocovat' vizuálne odkazy" je nespochybnitel'ne jednou z najdôležitejších kompetencií učitel'a výtvarného umenia. Vizualita ako taká je vo výtvarnej kultúre implicitne obsiahnutá, a preto vnímanie, chápanie a schopnost' interpretácie vizuálnych fenoménov u zdravých jedincov považujeme za rozvíjatel'nú kompetenciu. V edukačnej praxi sme však konfrontovaní so skutočnost'ou, že naši študenti - budúci učitelia výtvarného umenia, prichádzajúci na štúdium po absolvovaní rôznych typov stredných škôl, majú v predmetných oblastiach isté rezervy. Preto v rámci ich pregraduálnej prípravy vynakladáme maximálne úsilie pre 
rozvoj ich kompetencií voblasti kritického (hodnotiaceho) myslenia a tvorivosti. $\mathrm{V}$ rámci našej edukačnej praxe uplatňujeme, prirodzene, aj metódu demonštrácie umeleckého diela (či už vo forme originálu alebo sprostredkovaného $\mathrm{v}$ rôznych formách), ktoré sa stáva vizuálnym podnetom v procese interpretácie. Pri mapovaní základných pedagogických dokumentov vo vzt'ahu $\mathrm{k}$ vyššiemu sekundárnemu vzdelávaniu v snahe nájst' informácie o tom, do akej miery je termín vizuálny podnet $\mathrm{v}$ nich obsiahnutý, zaujalo nás, že termín vizuálny podnet sa uplatňuje iba v súvislosti s maturitnou skúškou z cudzích jazykov. Vyhláška Ministerstva školstva Slovenskej republiky 318/2008 Z.z. z 23. júla 2008 o ukončovaní štúdia na stredných školách, ktorou podl’a $§ 93$ zákona č. 245/2008 Z.z. o výchove a vzdelávaní (školský zákon) a o zmene a doplnení niektorých zákonov ustanovujú medzi inými spôsoby ukončovania štúdia na stredných školách a podrobnosti o forme konania maturitnej skúšky, III. čast' prílohy, obsahujúca podrobnosti o spôsobe konania a obsahu ústnej formy internej časti maturitnej skúšky z cudzích jazykov (anglický, francúzsky, nemecký, ruský, taliansky, španielsky, pol'ský, chorvátsky) charakterizuje prvú z troch úloh (pre všetky úrovne náročnosti) nasledovne: „Úloha č. 1 - Vizuálny podnet (napr. obrázok, fotografia, komiks, graf, schéma a pod.) Žiak opišse predložený obrázok a hl'adá súvislosti medzi obrázkom a príslušnou maturitnou úlohou. Komisia hodnotí súvislost' opisu predloženého podnetu, lineárnost' (postupnost') vo vyjadrovani a adekvátne jazykové prostriedky zodpovedajúce danej úrovni žiaka". (Vyhláška 318/2008 Z.z., 2008). Myslíme si, že úloha opisovaná vyššie môže byt' vhodným nástrojom na overenie kompetencií súčasnej mladej generácie nielen vo vzt’ahu $\mathrm{k}$ cudzojazyčnému vzdelávaniu. Rozhodli sme sa overit' kompetencie študentov - budúcich učitel'ov výtvarného umenia vo vzt’ahu k uplatneniu skúseností, vedomostí a poznatkov nadobudnutých poznávaním umeleckých diel počas vysokoškolského vzdelávania $\mathrm{v}$ súvislosti $\mathrm{s}$ interpretáciou vizuálnych podnetov mimoumeleckej povahy. Tieto kompetencie predpokladajú kritické (hodnotiace) a tvorivé myslenie, vrátane schopnosti komparovat', nachádzat' analógie, súvislosti a skryté významy.

\section{Teoretické východiská}

Vizuálna gramotnost' je nevyhnutnou kompetenciou pre úspešné fungovanie a spoločenské uplatnenie každého jedinca súčasnej doby, preto je logické, že danej problematike sa z rôznych aspektov venuje značná pozornost' (Sinatra, 1986, Stokes, 2002, Zanin-Yost et Donaldson, 2005). Komplexný pohl'ad na problematiku vizuálnej gramotnosti v slovenskom jazyku prináša Šupšáková (2015). V procese rozvíjania vizuálnej gramotnosti s dôrazom na kritické myslenie $\mathrm{v}$ podmienkach pregraduálnej prípravy budúcich učitelov výtvarného umenia za relevantné považujeme interpretačné postupy výtvarného diela uplatňujúce komparatívnu a semiotickú analýzu. Komparatívnu metódu uplatňujú mnohé vedné disciplíny, pričom preferujú a akcentujú rôzne aspekty porovnávania skúmaných javov (Van Tieghem, 1931, Wellek, 1969, Jauss, 1982, Zemanek, Nebrig, 2012). Komparácia, resp. komparatívne kompetencie vo vzt’ahu $\mathrm{k}$ výtvarnej edukácii s dôrazom na prípravu budúcich učitel’ov výtvarného umenia predstavujú komplex 
navzájom súvisiacich objektívnych a subjektívnych indikátorov potvrdzujúcich univerzálny charakter výtvarného jazyka, resp. výtvarných výrazových prostriedkov. Komparatívna metóda sa vo vysokoškolskej príprave učitel'ov výtvarného umenia využíva najmä $\mathrm{v}$ rámci disciplín zameraných na teóriu a dejiny výtvarného umenia. V našej edukačnej praxi sa ako vhodná komparatívna metóda uplatnitel'ná $\mathrm{v}$ rámci predmetov zameraných na vývoj umenia do 19. storočia ukazuje pät dvojíc tzv. "základných pojmov dejín umenia", definovaných švajčiarskym historikom a filozofom umenia Henrichom Wölfflinom v roku 1915, ktorý vo svojom diele Kunstgeschichtliche Grundbegriffe (Wölfflin, 1915) na základe týchto dvojíc interpretoval rozdiely medzi dvomi spôsobmi „videnia“ a zobrazovania porovnávaním renesančných a barokových výtvarných diel (pozri tiež Wölfflin, 1888). Ním vytvorené dvojice: 1. lineárne a malebné (nem. das Linerae und das Malerische), 2. plocha a híbka (nem. Fläche und Tiefe), 3. uzavretá a otvorená forma (nem. geschlossene Form und offene Form), Wölfflinom táto dvojica ešte spresnená ako tektonickost' a atektonickost' (nem. tektonisch und atektonisch), 4. mnohost' a jednota (nem. Vielheit und Einheit), Wölfflinom spresnená ako mnohoraká jednota a jednotná jednota (nem. vielheitliche Einheit und einheitliche Einheit), 5. jasnost' a nejasnost' (nem. Klarheit und Unklarheit), Wölfflinom spresnená ako bezpodmienečná a podmienená jasnost' (nem. unbedingte und bedingte Klarheit). Pomocou Wölfflinových dvojíc a ikonografie je možné interpretovat' - formálne i obsahovo analyzovat', syntetizovat' a komparovat' celý rad výtvarných diel popisovaním a rozoberaním námetov, ich typológie a atribútov. U študentov učitel'stva výtvarného umenia však rozvíjame aj kompetencie pre interpretáciu významu umeleckých diel v geografických, historických, kultúrnych, religióznych a filozofických súvislostiach, uplatnením ikonológie. Ikonológia ako metodologická koncepcia dejín umenia, interpretujúca dielo v rôznych významových vrstvách, sa formovala koncom 19. storočia vd'aka nemeckému historikovi umenia Abymu Warburgovi, ktorý túto metódu uplatnil prvý krát v roku 1892 pri analýze dvoch Botticelliových diel (Zrodenie Venuše a Primavera) a neskôr ju i pomenoval. Ikonológiu Abyho Warburga rozvinul v 30-tych rokoch 20. storočia nemecký historik umenia Erwin Panofsky (Panofsky, 2013) do trojstupňovej metodologickej koncepcie pozostávajúcej $\mathrm{z}$ tzv. preikonografického popisu (nem. präikonographische Analyse), ikonografickej analýzy (nem. ikonographische Analyse) a ikonologickej syntézy (nem. ikonologische Interpretation). Prvý stupeň prvotného, resp. prirodzeného vizuálneho významu predpokladá naše základné skúsenosti a verbálne zručnosti, opiera sa o poznanie dejín štýlov, ktoré v jednotlivých obdobiach ovplyvňovali spôsob stvárňovania predmetov, resp. motívov a dejov. Druhý stupeň predstavujúci sekundárny alebo konvenčný význam objektu ako sveta alegórií a príbehov, predpokladá hlbšie poznanie literárnych zdrojov a znalost' typológie atribútov konkrétnych námetov a postáv $\mathrm{v}$ dejinných súvislostiach. Tretí stupeň predstavujúci ikonologickú syntézu predpokladá poznanie kultúrnych javov v širších geografických, filozofických, religióznych i politických súvislostiach. Je to svet vnútorných hodnôt a symbolov, ktoré môžu mat' historický, aktuálny, univerzálny alebo 
regionálny význam. V priebehu 20. storočia vznikli d'alšie koncepcie akcentujúce filozofický, sociologický, psychologický, etický, masovokomunikačný a masovo-kultúrny rozmer (H. M. McLuhan, C. G. Jung, R. Arnheim, V. Flusser, W. Benjamin), resp. d'alšie súvislosti interpretácie umenia v období postmoderny (M. P. Foucault, U. Eco, J.-F. Lyotard, G. Deleuze, J. Derrida, atd'.). Poznanie uvedených, ako aj súčasných tendencií bezpochyby obohatí proces percepcie, recepcie a interpretácie umeleckých diel v kontexte výtvarnej edukácie.

Pri semiotickej analýze $\mathrm{v}$ rámci interpretácie výtvarných diel v podmienkach vysokoškolskej prípravy budúcich učitel'ov výtvarného umenia sa opierame o teóriu semiotika Charlesa Sandersa Peircea (In Bergman, Paavola, 2014), podla ktorej chápeme umelecké dielo ako špecifický súbor znakov a nimi nesených významov v zmysle triády icon (angl. Likeness) - interpretovaného na základe analógie, vonkajšej podobnosti, resp. objektívnej zhody, index (angl. Sign) - interpretovaného na základe vecnej (kauzálnej, resp. fyzickej) súvislosti a symbol (angl. General sign) - interpretovaného na základe dohody, tradície, resp. konvencie.

Vyššie uvedené postupy $\mathrm{v}$ rámci výtvarnej edukácie považujeme za relevantné teoretické východiská pre diferencovanie medzi formálnou, obsahovou a významovou rovinou vizuálnej kultúry a pochopenie týchto rozdielov zo strany študentov, zároveň uplatňovanie týchto postupov v rámci výučby vnímame ako adekvátny nástroj rozvoja kritického myslenia a tvorivosti študentov.

\section{Interpretácia vizuálneho podnetu ako stratégia rozvoja kritického a tvorivého myslenia s dôrazom na rozvoj kompetencií budúcich učitel’ov výtvarného umenia}

\subsection{Ciele výskumu}

Ciel'om nášho výskumu bolo zistit', akými kompetenciami disponujú študenti - budúci učitelia výtvarného umenia $\mathrm{v}$ oblasti vizuálnej gramotnosti vo vzt’ahu k predpokladaným skúsenostiam nadobudnutým počas pregraduálnej prípravy v bakalárskom a magisterskom stupni štúdia s dôrazom na poznatky a zručnosti, osvojené $\mathrm{v}$ rámci teoretických disciplín zameraných na teóriu a dejiny výtvarného umenia. Za relevantné považujeme tu zdôraznit', že $\mathrm{v}$ rámci predmetov zameraných na teóriu a dejiny výtvarných umení, je u študentov - budúcich učitel'ov výtvarného umenia systematicky rozvíjané kritické i tvorivé myslenie. V bakalárskom stupni sa študenti zaoberajú umením v diachrónnom aj synchrónnom aspekte, vrátane svetovej, európskej i domácej výtvarnej kultúry. Analýza a interpretácia výtvarného diela $\mathrm{v}$ magisterskom stupni vzdelávania zo strany študentov vzhl'adom a $\mathrm{v}$ nadväznosti na štruktúru študijného programu v bakalárskom stupni štúdia už predpokladá istú predispozíciu, adekvátne znalosti a zručnosti. Pri exegetickej interpretácii vytypovaných výtvarných diel si študent osvojuje metódy umelecko-historickej analýzy, úzko súvisiacej s archetypovou, genealogickou, štylistickou, formálnou, resp. tvarovou, taxonomickou, genologickou, obsahovou, štatistickou a kompozičnou analýzou, pri komparatívnej a semiotickej analýze si študent rozvíja kritické myslenie a 
overuje si svoje nadobudnuté znalosti v interdisciplinárnom i intermediálnom kontexte. Pri tzv. stvárňujúcej interpretácii v rámci možností seminárov $\mathrm{k}$ teoretickým disciplínam je vytvorený priestor pre tvorivú praktickú reflexiu podnetov z dejín umenia a širokej škály vizuálnej kultúry.

Našim zámerom bolo zistit', či sú študenti pripravení a kompetentní uplatnit' svoje poznatky, vedomosti a zručnosti nadobudnuté počas štúdia vo vzt'ahu k identifikácii analógie (ikon), vecnej súvislosti (index) a konvencie (symbol) $\mathrm{v}$ zmysle Peirceovej teórie znakov, a to formou interpretácie mimoumeleckých vizuálnych podnetov. A našou ambíciou bolo tiež zist'ovat', či druh strednej školy (umelecky alebo neumelecky zameranej) absolvovanej responedentmi pred vysokoškolským štúdiom bude mat' vplyv na kompetencie respondentov v skúmanej oblasti. Našim ciel'om bolo tiež skúmat', či predmet Analýza a interperetácia výtvarného diela zaradený do študijného programu $\mathrm{v}$ magisterskom stupni štúdia bude mat' (pozitívny) vplyv na výsledky - odpovede študentov reflektujúce ich kompetencie vo vzt’ahu k vyššie uvedeným súvislostiam teórie znakov: ikon - index symbol.

Uplatnenie neumeleckých vizuálnych podnetov v rámci nášho výskumu bolo zámerné s ciel’om zabezpečit' percepciu, recepciu a interpretáciu univerzálneho „obrazu“, nezat’aženého umelecko-historickými, resp. vizuálnymi skúsenost’ami respondentov a tak overit' efektivitu našej výučby realizovanej $\mathrm{v}$ rámci disciplín zameraných na teóriu a dejiny výtvarného umenia.

\subsection{Hypotézy výskumu}

Predpokladali sme, že:

1. Na základe obrázku znázorňujúceho dve rozdielne jablká naši respondenti - absolventi stredných umeleckých škôl pomenujú vo vzt’ahu k predmetnému obrázku širšie spektrum kvalitatívnych (formálnych i obsahových) vzt'ahových relácií než respondenti absolventi neumeleckých stredných škôl.

2. V magisterskom stupni štúdia učitel'stva výtvarného umenia bude viac takých respondentov, ktorí v súvislosti s obrázkom jablka asociujú ikonografické a ikonologické súvislosti tohto predmetu ako atribútu viacerých mytologických príbehov, než v bakalárskom stupni štúdia učitel'stva výtvarného umenia.

\subsection{Plán výskumu a výskumný súbor}

Našu výskumnú vzorku tvorilo 143 respondentov, z toho 98 študujúcich v akademickom roku 2018/2019 v dennej forme štúdia v študijnom programe Učitel'stvo výtvarného umenia, konkrétne $\mathrm{v} 1$. ročníku $\mathrm{Bc}$. stupňa 38 študentov, v 2. ročníku Bc. stupňa 16 študentov, v 3. ročníku Bc. stupňa 16 študentov, v 1. ročníku Mgr. stupňa 8 študentov, v 2. ročníku Mgr. stupňa 20 študentov, a 45 frekventantov d’alšieho vzdelávania v rámci Univerzity tretieho veku UKF v Nitre vo vzdelávacom programe Deiiny výtvarného umenia a výtvarná tvorba na Katedre výtvarnej tovrby a výchovy Pedagogickej fakulty Univerzity Konštantína Filozofa v Nitre. Dotazník vyplnili frekventanti univerzity tretieho veku študujúci $\mathrm{v}$ uvedenom 
vzdelávacom programe $\mathrm{v}$ dvoch ročníkoch $-\mathrm{v} 2$. a 3. ročníku 1. stupňa tohto vzdelávania (1. ročník má $\mathrm{v}$ zimnom semestri všeobecný základ vzdelávania zabezpečovaný inými pracoviskami) a vo všetkých troch ročníkoch 2 . stupňa tohoto vzdelávania. Zaradenie frekventantov univerzity tretieho veku do výskumu malo za ciel' získat' vyjadrenia aj od skupiny respondentov, ktorí predstavujú markantne vyššiu vekovú kategóriu (45+ rokov) a teda možno u nich predpokladat', že disponujú viacerými (nielen) vizuálnymi skúsenost’ami než respondenti študujúci $v$ dennej forme štúdia, cielene sa pripravujúci na učitel'stvo výtvarného umenia $(19-25$ rokov $)$. Naopak v porovnaní s dennými študentmi magisterského stupňa štúdia, vychádzajúc z charakteru a koncepcie záujmového vzdelávania $\mathrm{v}$ rámci univerzity tretieho veku, neabsolvovali predmet so zameraním na analýzu a interpretáciu výtvarného umenia, ktorý je zacielený na teoretické aj praktické aspekty percepcie, recepcie a interpretácie umeleckých diel vizuálnej kultúry vrátane osvojovania odbornej terminológie $\mathrm{v}$ kontexte vyššie uvedených ikonografických a ikonologických koncepcií.

Našu výskumnú vzorku tvorilo 19 mužov a 124 žien, podl'a jednotlivých stupňov, resp. druhu vzdelávania $\mathrm{v}$ nasledovnom zložení: na bakalárskom stupni štúdia 14 mužov a 56 žien, na magisterskom stupni štúdia 2 muži a 26 žien, na univerzite tretieho veku 3 muži a 42 žien. Ohl'adom absolvovanej strednej školy pred nástupom na vysokú školu u respendentov bakalárskeho a magisterského stupňa štúdia (kde je táto informácia vo vzt’ahu nami stanovenej hypotézy relevantná) sme zistili nasledovné: z 98 študentov bakalárskeho a magisterského štúdia 57 absolvovalo neumeleckú strednú školu (d'alej NUŠ) a 41 respondentov absolvovalo strednú školu s umeleckým zameraním (d’alej UŠ). Podl’a jednotlivých ročníkov a stupňa vzdelávania v nasledovnom zložení: v 1. ročníku Bc. stupňa štúdia 24 NUŠ, 14 respondentov UŠ, v 2. ročníku Bc. stupňa štúdia 10 respondentov NUŠ, 6 respondentov UŠ, v 3. ročníku Bc. stupňa štúdia 8 respondentov NUŠ, 8 respondentov UŠ, v 1. ročíku Mgr. stupňa štúdia 4 respondenti NUŠ, 4 respondenti UŠ, v 2. ročníku Mgr. stupňa štúdia 11 respondentov NUŠ. 9 respondentov UŠ. Vyjadrené v percentách, 58 \% našich respondentov v Bc. a Mgr. stupni štúdia sú absolventmi stredných škôl, resp. gymnázií s neumeleckým zameraním, zvyšných $42 \%$ absolvovalo strednú školu s umeleckým zameraním..

\subsection{Metódy výskumu}

Metódou získavania dát bol anonymný dotazník obsahujúci okrem úvodných základných otázok 7 položiek. Základnými úvodnými otázkami sme zistovali afiliáciu respondenta $\mathrm{k}$ príslušnému študijnému, resp. vzdelávaciemu programu a ročníku štúdia, zameranie predchádzajúceho stredoškolského, resp. vysokoškolského vzdelania a pohlavie.

Prvých šest' položiek obsahovalo vizuálny podnet - fotografie s tromi otvorenými otázkami:

1. Čo zobrazuje (znázorňuje) obrázok?

2. Čo asociujete (aké predstavy, súvislosti spájate) s predmetom na obrázku?

(uved'te minimálne 5 asociácií) 
3. Čo symbolizuje (významovo vyjadruje) predmet na obrázku?

Konkretizácia obsahu obrázkov: obrázok č. 1 - jedno jablko, obrázok č. 2 dve jablká, obrázok č. 3 - zatvorená kniha, obrázok č. 4 - otvorená kniha, obrázok č. 5 - prázdna plastová dóza, obrázok č. 6 - plastová dóza obsahujúca menší predmet.

Položka č. 7 obsahovala všetkých 6 predchádzajúcich obrázkov z dotazníka ako súbor vizuálneho podnetu. Táto položka obsahovala iba jedno zadanie $\mathrm{v}$ znení: Ak si pozriete obrázky č. 1. - 6. spolu, čo asociujete (aké predstavy spájate, č osa Vám vynorí v pamäti), v súvislosti s týmito obrázkami prípadne aký príbeh vo vás evokujú tieto obrázky?

Dotazník bol zámerne koncipovaný tak, že v textácii zadaní sa neuvádzajú žiadne formulácie a definície vyššie uvedených autorov našich teoretických východísk, $\mathrm{s}$ ktorými sa naši respondenti mali možnost' oboznamovat' $\mathrm{v}$ rámci výučby. Sledovali sme tým náš záujem zistit' schopnost' respondentov aplikovat' tieto vedomosti a poznatky v praxi.

Výskum sa realizoval počas výučbového obdobia zimného semestra akademického roka 2018/2019. Metódou spracovania dát sa stala kvantitatívna a kvalitatívna analýza odpovedí z dotazníkov, premietnutých do slovnej interpretácie odpovedí, ako aj overenie, resp. zhodnotenie hypotéz.

Vzhl'adom na charakter dotazníka s položkami s otvorenými otázkami a našu ambíciu odvolávat' sa $\mathrm{v}$ interpretácii výsledkov na vyjadrenia a formulácie výpovedí našich respondentov, každý vyplnený dotazník bol po zbere dát označený atribúciou podl'a nasledovného kl'úča: číselné označenie ročníka (1, 2, alebo 3), skratka študijného, resp. vzdelávacieho programu (Bc bakalársky stupeň, Mgr - magisterský stupeň, U3V - univerzita tretieho veku, 1. stupeň, U3Vd - univerzita tretieho veku, 2. stupeň), poradové č́slo ( 1 - počet respondentov $\mathrm{v}$ danej skupine). Naše dotazníky boli teda označené ako: 1Bc1 - 38, 2Bc1 - 16, 3Bc1 - 16, 1Mgr1 - 8, 2Mgr1 - 20, 2U3V1 - 10, 3U3V1 - 11, 1U3Vd1 - 7, 2U3Vd1 - 9, 3U3Vd1 - 8 .

$\mathrm{V}$ rámci tohto príspevku zameriame našu pozornost' na interpretáciu výsledkov získaných z odpovedí respondentov v súvislosti s položkami 1 a 2 nášho dotazníka (pozri obrázok č. 1 zobrazujúce jedno jablko a obrázok č. 2 zobrazujúce dve jablká).

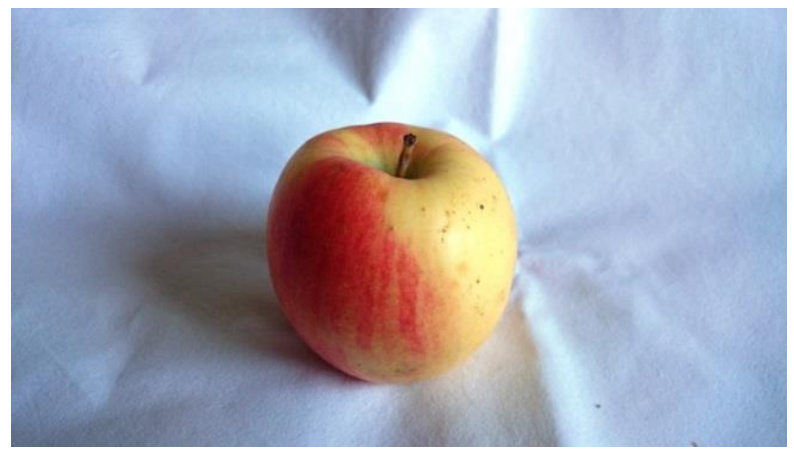

Obrázok 1. Jedno jablko (Foto: Adriana Récka, 2018) 


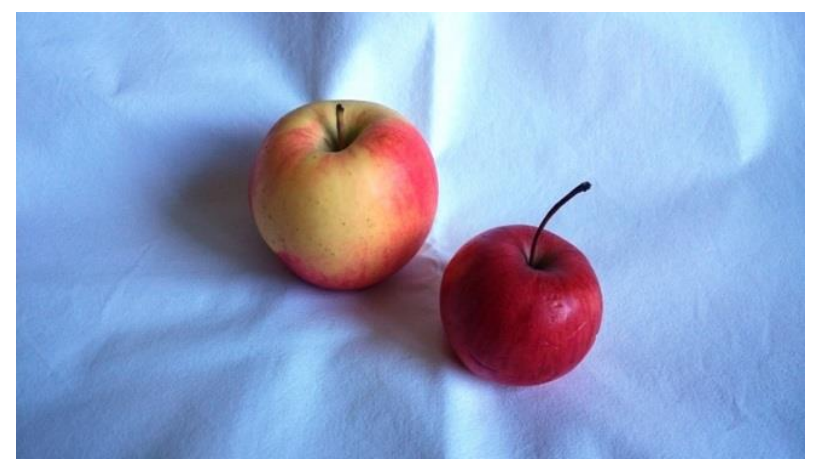

Obrázok 2. Dve jablká (Foto: Adriana Récka, 2018)

\subsection{Výsledky vóskumu}

Parciálne výsledky nášho výskumu $\mathrm{v}$ kvantitatívnej aj kvalitatívnej forme sme publikovali $\mathrm{v}$ zahraničnom periodiku (Récka, 2018). Ako sme uviedli vyššie, $v$ rámci tohto príspevku prinesieme interpretáciu výsledkov získaných $\mathrm{z}$ odpovedí respondentov $\mathrm{v}$ súvislosti s položkami 1 a 2 nášho dotazníka a vyhodnotením nami stanovených hypotéz. $\mathrm{V}$ tabul'kovej podobe prinášame informácie vo vzt’ahu $\mathrm{k}$ frekventovaným termínom našich respondentov $\mathrm{v}$ oblasti terminológie teórie umenia, $\mathrm{k}$ termínom $\mathrm{v}$ socio-psychologickobiologicko-emocionálnej oblasti a k termínom voblasti ikonogografie. V tabul'kách uvádzame frekvenciu respondentmi uvedených termínov vo vzt’ahu k ročníkom aj stupňu, resp. druhu štúdia, a v niektorých prípadoch pre úplnost' informácií uvádzame výsledok aj v percentách. Najvyššie hodnoty zároveň farebne zvýrazňujeme.

Našou prvou hypotézou sme sledovali kompetencie respondentov v oblasti kritického (hodnotiaceho) myslenie s dôrazom na identifikáciu formálnych i obsahových relácií vizuálnych podnetov. Naša prvá hypotéza sa nepotvrdila, naši respondenti - absolventi stredných umeleckých škôl na základe obrázku znázorn̆ujúceho dve rozdielne jablká nepomenovali vo vzt'ahu k predmetnému obrázku širšie spektrum, resp. väčší počet kvalitatívnych (formálnych i obsahových) vzt’ahových relácií než respondenti - absolventi neumeleckých stredných škôl. Výsledky priniesli zároveň niekol'ko zaujímavých zistení. Celkovo respondenti uviedli široké spektrum kvalitatívnych vzt’ahových relácií, ktoré môžeme klasifikovat' jednak ako pojmy $\mathrm{z}$ teórie umenia súvisiace $\mathrm{s}$ hodnotením formálnej, resp. vizuálnej stránky daných podnetov, jednak ako pojmy súvisiace so sociálnopsychologickým, biologickým, resp. emocionálnym aspektom percepcie vizuálnych podnetov. V skupine pojmov z teórie umenia boli najfrekventovanejšie pojmy: farba, kontrast, svetlo, tieň, odlišnost', rozdielly, vzt’ah, kompozícia, zátišie, červené, malé, vel'ké, väčšie, menšie (pozri tabul'ku č. 1).

Tabul'ka 1. Frekventované termíny z teórie umenia

\begin{tabular}{|l|l|l|l|l|l|l|l|}
\hline $\begin{array}{l}\text { Frekventova } \\
\text { né termíny }\end{array}$ & $\begin{array}{l}\text { 1. roč. } \\
\text { Bc. }\end{array}$ & $\begin{array}{l}\text { 2. roč. } \\
\text { Bc. }\end{array}$ & $\begin{array}{l}\text { 3. roč. } \\
\text { Bc. }\end{array}$ & $\begin{array}{l}\text { 1. } \\
\text { roč. }\end{array}$ & $\begin{array}{l}2 . \\
\text { roč. }\end{array}$ & $\mathbf{4 3}$ & Spolu \\
z teórie & $\mathbf{3 8}$ & $\mathbf{1 6}$ & 16 & Mgr. & Mgr. & & \\
\hline
\end{tabular}




\begin{tabular}{|c|c|c|c|c|c|c|c|}
\hline umenia & & & & 8 & 20 & & \\
\hline farba & $\begin{array}{l}13 / 34 \\
\%\end{array}$ & $\begin{array}{l}14 / 58 \\
\%\end{array}$ & $3 / 19 \%$ & $\begin{array}{l}2 / 25 \\
\%\end{array}$ & $\begin{array}{l}6 / 30 \\
\%\end{array}$ & $\begin{array}{l}37 / 58 \\
\%\end{array}$ & $\begin{array}{l}75 / 52 \\
\%\end{array}$ \\
\hline zátišie & $\begin{array}{l}14 / 37 \\
\%\end{array}$ & $\begin{array}{l}10 / 63 \\
\%\end{array}$ & $\begin{array}{l}11 / 69 \\
\%\end{array}$ & $\begin{array}{l}3 / 38 \\
\%\end{array}$ & $\begin{array}{l}8 / 40 \\
\%\end{array}$ & $\begin{array}{l}16 / 34 \\
\%\end{array}$ & $\begin{array}{l}62 / 43 \\
\%\end{array}$ \\
\hline červené & 7 & 3 & $5 / 31 \%$ & 0 & 3 & $\begin{array}{l}14 / 31 \\
\%\end{array}$ & $\begin{array}{l}32 / 22 \\
\%\end{array}$ \\
\hline $\mathrm{rozdiel} / \mathrm{y}$ & 10 & $6 / 38 \%$ & 2 & 2 & 1 & 4 & $\begin{array}{l}25 / 18 \\
\%\end{array}$ \\
\hline malé & 6 & 3 & 3 & 1 & 2 & $\begin{array}{l}10 / 22 \\
\%\end{array}$ & $\begin{array}{l}25 / 18 \\
\%\end{array}$ \\
\hline odlišnost' & 10 & 4 & 2 & $\begin{array}{l}3 / 38 \\
\%\end{array}$ & 2 & 3 & $\begin{array}{l}24 / 17 \\
\%\end{array}$ \\
\hline kontrast & 7 & $7 / 44 \%$ & 1 & 2 & 3 & 3 & $\begin{array}{l}23 / 16 \\
\%\end{array}$ \\
\hline vzt'ah & 7 & $7 / 44 \%$ & 3 & 2 & 3 & 0 & $\begin{array}{l}22 / 15 \\
\%\end{array}$ \\
\hline tieň & 2 & 2 & 0 & 2 & 0 & $\begin{array}{l}10 / 22 \\
\%\end{array}$ & $\begin{array}{l}16 / 11 \\
\%\end{array}$ \\
\hline svetlo & 2 & $4 / 25 \%$ & 1 & 0 & 2 & 5 & $\begin{array}{l}14 / 10 \\
\%\end{array}$ \\
\hline vel'ké & 2 & $2 / 13 \%$ & 1 & 1 & 1 & 4 & $11 / 8 \%$ \\
\hline kompozícia & 4 & 3 & 0 & $\begin{array}{l}2 / 25 \\
\%\end{array}$ & 1 & 1 & $11 / 8 \%$ \\
\hline väčšie & 3 & 1 & 1 & 0 & 1 & $4 / 9 \%$ & $10 / 7 \%$ \\
\hline menšie & 2 & 1 & 1 & 0 & 1 & $4 / 9 \%$ & $9 / 6 \%$ \\
\hline
\end{tabular}

Zdroj: Adriana Récka, 2018

Markantne bohatšia je slovná zásoba našich respondentov v sociálnopsychologickej, emocionálnej a biologickej oblasti, respondenti asociovali široké spektrum konkrétnych i abstraktných pojmov: zdravie/zdravý, jeseň, ovocie, chut', vitamíny, život/životný štýl, sladké, strom, štavnaté, jedlo, priatel'stvo, vzt’ah, záhrada, koláč, Snehulienka, výživa/výživné, pár, teplý (pocit) ne/zrelost', hlad, Vianoce, zber (úrody), diet'a, dvojica, rodina, ochrana, kyslost'kyslé, súdržnost', rodič, babka, manželstvo, partnerstvo, detstvo, muž, žena (pozri tabul'ku č. 2).

Tabul'ka 2. Frekventované asociované socio-psychologicko-biologické terminy

\begin{tabular}{|l|l|l|l|l|l|l|l|}
\hline $\begin{array}{l}\text { Frekventon } \\
\text { é asociované } \\
\text { socio- } \\
\text { psychologic } \\
\text { ko- } \\
\text { biologické } \\
\text { termíny }\end{array}$ & $\begin{array}{l}\mathbf{1 .} \\
\text { roč. } \\
\text { Bc. } \\
\mathbf{3 8}\end{array}$ & $\begin{array}{l}\mathbf{2 .} \\
\text { roč. } \\
\text { Bc. } \\
\mathbf{1 6}\end{array}$ & $\begin{array}{l}\mathbf{3 .} \\
\text { roč. } \\
\text { Bc. } \\
\mathbf{1 6}\end{array}$ & $\begin{array}{l}\mathbf{1 .} \\
\text { roč. } \\
\text { Mgr. } \\
\mathbf{8}\end{array}$ & $\begin{array}{l}\mathbf{2 .} \\
\text { roč. } \\
\text { Mgr. } \\
\mathbf{2 0}\end{array}$ & $\begin{array}{l}\text { U3V } \\
\mathbf{4 5}\end{array}$ & $\begin{array}{l}\text { Spolu } \\
\mathbf{1 4 3}\end{array}$ \\
\hline $\begin{array}{l}\text { zdravie/zdra } \\
\text { vý }\end{array}$ & $\begin{array}{l}20 / 53 \\
\%\end{array}$ & $\begin{array}{l}13 / 81 \\
\%\end{array}$ & $\begin{array}{l}15 / 94 \\
\%\end{array}$ & $2 / 25 \%$ & $\begin{array}{l}16 / 80 \\
\%\end{array}$ & $\begin{array}{l}33 / 73 \\
\%\end{array}$ & $\begin{array}{l}99 / 69 \\
\%\end{array}$ \\
\hline jesen̆ & $24 / 63$ & $10 / 63$ & $5 / 31 \%$ & $3 / 38 \%$ & $15 / 75$ & $25 / 56$ & $83 / 58$ \\
\hline
\end{tabular}




\begin{tabular}{|c|c|c|c|c|c|c|c|}
\hline & $\%$ & $\%$ & & & $\%$ & $\%$ & $\%$ \\
\hline ovocie & $9 / 24 \%$ & $5 / 31 \%$ & $9 / 56 \%$ & $\begin{array}{l}22 / 25 \\
\%\end{array}$ & $\begin{array}{l}10 / 50 \\
\%\end{array}$ & $\begin{array}{l}17 / 38 \\
\%\end{array}$ & $\begin{array}{l}52 / 36 \\
\%\end{array}$ \\
\hline chut' & $\begin{array}{l}10 / 26 \\
\%\end{array}$ & $3 / 19 \%$ & $5 / 31 \%$ & $2 / 25 \%$ & $6 / 30 \%$ & $\begin{array}{l}23 / 51 \\
\%\end{array}$ & $\begin{array}{l}51 / 36 \\
\%\end{array}$ \\
\hline vitamíny & $4 / 11 \%$ & $2 / 13 \%$ & $6 / 38 \%$ & $1 / 13 \%$ & $4 / 20 \%$ & $\begin{array}{l}20 / 44 \\
\%\end{array}$ & $\begin{array}{l}37 / 26 \\
\%\end{array}$ \\
\hline $\begin{array}{l}\text { život/životný } \\
\text { stýl }\end{array}$ & 12 & 5 & $6 / 38 \%$ & 1 & 4 & 5 & $\begin{array}{l}33 / 23 \\
\%\end{array}$ \\
\hline sladké & 8 & 1 & 5 & 2 & $8 / 40 \%$ & 9 & $\begin{array}{l}33 / 23 \\
\%\end{array}$ \\
\hline strom & 9 & 2 & 5 & 1 & $8 / 40 \%$ & 7 & $\begin{array}{l}32 / 22 \\
\%\end{array}$ \\
\hline štavnaté & 1 & 0 & 2 & 0 & 4 & $\begin{array}{l}20 / 44 \\
\%\end{array}$ & $\begin{array}{l}27 / 19 \\
\%\end{array}$ \\
\hline jedlo & 7 & 2 & 3 & 2 & $7 / 35 \%$ & 5 & $\begin{array}{l}26 / 18 \\
\%\end{array}$ \\
\hline priatel'stvo & $\begin{array}{l}13 / 34 \\
\%\end{array}$ & 1 & 2 & 2 & 3 & 1 & $\begin{array}{l}22 / 15 \\
\%\end{array}$ \\
\hline vzt'ah & 7 & $7 / 44 \%$ & 3 & 2 & 3 & 0 & $\begin{array}{l}22 / 15 \\
\%\end{array}$ \\
\hline záhrada & 2 & 1 & $5 / 31 \%$ & 1 & 5 & 7 & $\begin{array}{l}21 / 15 \\
\%\end{array}$ \\
\hline koláć & 3 & 0 & $4 / 25 \%$ & 1 & $5 / 25 \%$ & 6 & 19 \\
\hline Snehulienka & 4 & 1 & $4 / 25 \%$ & 2 & $5 / 25 \%$ & 1 & 17 \\
\hline $\begin{array}{l}\text { výživa/výživ } \\
\text { né }\end{array}$ & 2 & 0 & 3 & 2 & $4 / 20 \%$ & 6 & 17 \\
\hline pár & 2 & 1 & 2 & $2 / 25 \%$ & 4 & 6 & 17 \\
\hline teplý (pocit) & 5 & 3 & 0 & $2 / 25 \%$ & 1 & 4 & 15 \\
\hline ne/zrelost' & 4 & $5 / 31 \%$ & 1 & 0 & 1 & 4 & 15 \\
\hline hlad & 5 & $5 / 31 \%$ & 1 & 0 & 2 & 2 & 15 \\
\hline Vianoce & 2 & 0 & 3 & 0 & 1 & $9 / 20 \%$ & 15 \\
\hline zber (úrody) & 1 & 0 & 1 & 0 & 3 & $9 / 20 \%$ & 14 \\
\hline diet'a & 4 & 1 & 1 & 0 & 2 & 2 & 10 \\
\hline dvojica & 1 & $4 / 25 \%$ & 1 & 0 & 1 & 3 & 10 \\
\hline rodina & 3 & 0 & 0 & 0 & 2 & 3 & 8 \\
\hline žena & 3 & 0 & 0 & 1 & 2 & 2 & 8 \\
\hline ochrana & 2 & 1 & 0 & 0 & 0 & 5 & 8 \\
\hline $\begin{array}{l}\text { kyslost'/kysl } \\
\text { é }\end{array}$ & 4 & 0 & 1 & 0 & 1 & 2 & 8 \\
\hline súdržnost' & 2 & 1 & 1 & 0 & 0 & 3 & 7 \\
\hline rodič & 4 & 1 & 1 & 0 & 0 & 0 & 6 \\
\hline babka & 3 & 1 & 1 & 0 & 0 & 1 & 6 \\
\hline manželstvo & 3 & 2 & 0 & 0 & 0 & 0 & 5 \\
\hline muž & 2 & 0 & 0 & 1 & 0 & 2 & 5 \\
\hline partnerstvo & 1 & 0 & 0 & 0 & 2 & 1 & 4 \\
\hline detstvo & 1 & 0 & 0 & 0 & 1 & 1 & 3 \\
\hline
\end{tabular}


Našou druhou hypotézou sme sledovali kompetencie respondentov v oblasti identifikácie a pomenovania ikonografických a ikonologických súvislostí s jablkom ako atribútom viacerých mytologických príbehov. Naša druhá hypotéza sa potvrdila. Na magisterskom stupni štúdia percento tých respondentov, ktorí $\mathrm{v}$ súvislosti s obrázkom jablka asociovali rôzne ikonografické a ikonologické súvislosti tohto predmetu ako atribútu viacerých mytologických príbehov bolo $60,7 \%$, v číselnom vyjadrení: v 1 . ročníku 2 z 8 opýtaných, v 2 . ročníku 15 z 20 opýtaných uviedlo nejakú súvislost'. Zvlášt' potešujúci je percentuálny pomer v 2. ročníku magisterského stupňa štúdia v skupine študentov, ktorí v letnom semestri 1. ročníka magisterského štúdia absolvovali predmet Analýza a interpretácia výtvarného diela. V rámci tohto predmetu cielene a systematicky vedieme študentov k nadobudnutiu vedomostí a zručností voblasti percepcie a recepcie vizuálnej kultúry. Náš výskum ukázal, že až $75 \%$ respondentov $\mathrm{z}$ uvedeného ročníka spája $\mathrm{s}$ jablkom mytologický kontext a vo svojich odpovediach operovali nielen termínmi Adam a Eva, rajská záhrada, zakázané ovocie, prvý hriech, ale vyskytli sa u nich aj pojmy pokušenie, had, strom poznania, dôvod vyhnania z raja, rozširujúce terminologickú základňu, ktorú uplatňovali naši respondenti - študenti bakalárskeho stupňa štúdia v súvislosti s týmto známym biblickým príbehom. Okrem asociácie tohto frekventovaného významu jablka sa d'alšie mytologické významy v odpovediach našich respondentov bakalárskeho a magisterského stupňa štúdia objavili skôr sporadicky. V bakalárskom stupni štúdia nás príjemne prekvapili dvaja respondenti (z 1. a 3. ročníka), ktorí si spomenuli nielen na biblický kontext jablka, ale uviedli asociáciu aj v súvislosti s gréckou mytológiou ako jablkom sváru (dôvod trójskej vojny). Úspešnejší bol význam jablka v spojitosti s plodnost'ou z gréckej mytológie, podla ktorej bohyňa zeme Gaia darovala bohyni Hére pri jej sobáši s Diom jablko ako symbol plodnosti. Pät' respondentov z uvedenej skupiny respondentov na Bc. a Mgr. stupni štúdia asociovalo jablko s prejavom lásky, známym tiež z antiky (pozri tabul'ku č. 3). Ďalší traja respondenti z bakalárskeho stupňa (v každom ročníku 1) asociovali Newtonov zákon o gravitácii (z celkového počtu 143 respondentov to uviedli iba títo traja respondenti), iba 1 respondent z celkového počtu všetkých (143) respondentov asocioval v súvislosti s jablkom známu značku skupiny osobných počítačov a smartfónov vyrábaných americkou spoločnost’ou. Prekvapila nás skutočnost', že spomedzi 143 respondentov iba 17 asociovalo v súvislosti s obrázkom jablka rozprávkovú postavu Snehulienky, hoci tento predmet je jej charakteristickým atribútom, a možno predpokladat', že naši respondenti sa s predmetnou rozprávkou počas svojho detstva stretli. Výsledky ukázali, že druh strednej školy, ktorú študenti absolvovali pred vysokoškolským štúdium, v našej skupine respondentov nemá rozhodujúci vplyv na kvalitu odpovedí. Zistili sme tiež, že naši respondenti v drvivej väčšine nerozlišujú medzi kategóriami obraz (ikon), znak (index) a význam (symbol), pojmy uvedené v tabul'ke č. 1, 2 a 3 spájali s jednotlivými kategóriami neadekvátne, často duplicitne (najmä vo vzt'ahu k indexu a symbolu , čo považujeme za 
negatívny jav vzhl'adom na skutočnost', že predmetnej problematike sme sa $\mathrm{v}$ skupine našich respondentov venovali systematicky a intenzívne $\mathrm{v}$ rámci prednášok i seminárov.

Tabul'ka 3. Frekventované ikonografické termíny

\begin{tabular}{|l|l|l|l|l|l|l|l|}
\hline $\begin{array}{l}\text { Frekventované } \\
\text { ikonografické } \\
\text { termíny }\end{array}$ & $\begin{array}{l}\mathbf{1 .} \\
\text { roč. } \\
\text { Bc. } \\
\mathbf{3 8}\end{array}$ & $\begin{array}{l}\mathbf{2 .} \text { roč. } \\
\text { Bc. }\end{array}$ & $\begin{array}{l}\mathbf{1 6} \\
\text { roč. } \\
\text { Bc. } \\
\mathbf{1 6}\end{array}$ & $\begin{array}{l}\mathbf{1 .} \\
\text { roč. } \\
\text { Mgr. } \\
\mathbf{8}\end{array}$ & $\begin{array}{l}\mathbf{2 .} \text { roč. } \\
\text { Mgr. } \\
\mathbf{2 0}\end{array}$ & $\begin{array}{l}\text { U3V } \\
\mathbf{4 5}\end{array}$ & $\begin{array}{l}\text { Spolu } \\
\mathbf{1 4 3}\end{array}$ \\
\hline prvý hriech & 4 & 2 & 3 & 1 & $11 / 55 \%$ & 4 & $25 / 17 \%$ \\
\hline Eva & 6 & $4 / 25 \%$ & 0 & 1 & $5 / 25 \%$ & 9 & $25 / 17 \%$ \\
\hline Adam & 6 & $4 / 25 \%$ & 0 & 1 & $5 / 25 \%$ & 7 & $23 / 16 \%$ \\
\hline raj/rajské & 1 & 1 & 1 & 1 & $7 / 35 \%$ & 9 & $20 / 14 \%$ \\
\hline plodnost' & 3 & $3 / 19 \%$ & 0 & 1 & 2 & 2 & $11 / 8 \%$ \\
\hline $\begin{array}{l}\text { zakázané } \\
\text { ovocie }\end{array}$ & 2 & 1 & 1 & 0 & $4 / 20 \%$ & 1 & $9 / 6 \%$ \\
\hline láska & 4 & $2 / 13 \%$ & 0 & 0 & 2 & 1 & $9 / 6 \%$ \\
\hline Biblia, biblické & 3 & 0 & 0 & 1 & $3 / 15 \%$ & 1 & $8 / 6 \%$ \\
\hline poznanie & 0 & 0 & 0 & 0 & $2 / 10 \%$ & 3 & $5 / 3,5 \%$ \\
\hline pokušenie & 0 & 1 & 1 & 0 & $2 / 10 \%$ & 0 & $4 / 3 \%$ \\
\hline jablko sváru & 1 & 0 & 1 & 0 & 0 & 1 & $3 / 2 \%$ \\
\hline
\end{tabular}

Zdroj: Adriana Récka, 2018

\section{Záver}

Našim výskumom sme zist’ovali kompetencie študentov - budúcich učitel'ov výtvarného umenia $\mathrm{v}$ oblasti vizuálnej gramotnosti vo vzt'ahu $\mathrm{k}$ predpokladaným skúsenostiam nadobudnutým počas pregraduálnej prípravy v bakalárskom a magisterskom stupni štúdia s dôrazom na poznatky a zručnosti, osvojené v rámci teoretických disciplín zameraných na teóriu a dejiny výtvarného umenia. Študenti prichádzajúci na vysokoškolské štúdium z rôznych typov stredných škôl disponujú zároveň rôznymi vstupnými poznatkami a skúsenost’ami. Výsledky nášho výskumu ukázali, že vo vzt’ahu ku kompetenciám, ktoré sme sledovali, druh absolvovanej strednej školy nezohráva rolu. Je pre nás potešujúce, že naše edukačné aktivity zamerané na diachrónne i synchrónne ponímanie vývoja dejín umenia najmä v rámci disciplíny Analýza a interpretácia výtvarného diela v 1. ročníku magisterského stupňa štúdia, sa ukazujú ako efektívny nástroj rozvoja kritického a tvorivého myslenia. Zistili sme, že naši respondenti operujú širokým spektrom termínov v oblasti interpretácie formálnych i obsahových aspektov vizuálnych fenoménov. Zistili sme však, že napriek našej snahe, väčšina respondentov nemá kompetenciu rozlišovat' medzi tromi rovinami (ikon - index - symbol) vnímania vizuálnych podnetov. Výsledky výskumu sú pre nás podnetom pre kreovanie budúcich edukačných aktivít aj v nižších ročníkoch s implementovaním takých foriem vzdelávania, ktoré budú zamerané na rozvíjanie interpretačných zručností vo vzt’ahu k formálnemu, obsahovému, ako aj k semiotickému aspektu vizuálnej kultúry umeleckej i mimoumeleckej povahy. 
Táto práca bola podporovaná Agentúrou na podporu výskumu a vývoja na základe Zmluvy č. APVV-15-0368“. Je výstupom projektu Prax v centre odborovej didaktiky, odborová didaktika v Centre praktickej prípravy

\section{Bibliographic references}

BERGMAN, M. - PAAVOLA, S. (edit.). 2003. The Commens Dictionary. Peirce's Terms in His Own Works. New Edition. New Edition 2014. First edition ISSN 2342-1320. Available online: http://www.commens.org/dictionary

BRISTOR, V. J. - DRAKE, S.V. 1994. Linking the Language Arts and Content Areas Though Visual Technology, T H E journal 22.2, pp. 74-78. Available online: https://www.questia.com/read/1G1-16175245/linking-thelanguage-arts-and-content-areas-through

JAUSS, H. R. 1982. Aesthetic Experience and Literary Hermeneutics. Minneapolis: University of Minnesota Press,. 400 p. ISBN 978-0-8166-10068 .

PANOFSKY, E. 2013. Vyznam ve vytvarnem umeni. Praha: Malvern: Academia, 444 p. ISBN 978-80-87580-37-0.

RECKA, A. 2018. Interpretation of Visual Inputs as a Tool For Measuring the Effectiveness of Fine Arts Education With an Emphasis on the Disciplines of Theory and Art History. In AD ALTA: Journal of Interdisciplinary Research. ISSN 1804-7890, vol. 8, no. 2, pp. 204-209.

SINATRA, R. 1986. Visual literacy connections to thinking, reading and writing. Springfield, IL: Charles C. Thomas, 307 p. ISBN: ISBN-0-39805192-5.

STOKES, S. 2002. Visual Literacy in Teaching and Learning: A Literature Perspective. Electronic journal for the integration of technology in education. Idaho State University, Available online: http://ejite.isu.edu/Volume1No1/Stokes.html

SUPSAKOVA, B. 2015. Vizualna gramotnost. Brno: Tribun EU, 138 p. ISBN 978-80-363-0934-5.

VAN TIEGHEM, P. 1931. La litterature comparee. Paris: A. Colin, 222 p.

Vyhlaska 318/2008 Z.z., 2008. Vyhlaska Ministerstva skolstva Slovenskej republiky 318/2008 Z.z. z 23. jula 2008 o ukoncovani studia na strednych skolach. 2008. Available online: https://www.slov-lex.sk/pravnepredpisy/SK/ZZ/2008/318/20160901.

WELLEK, R. 1963. Concepts of criticism. New Haven: Yale University Press, 420 p. ISBN: 978-0-3000-9463-3.

WOLFFLIN, H. 1915. Kunstgeschichtliche Grundbegriffe : das Problem der Stilentwicklung in der neueren Kunst. Munchen: F. Bruckmann, 255 p. Available online: https://digi.ub.uniheidelberg.de/diglit/woelfflin1915/0007/image WOLFFLIN, H.1888 Renaissance und Barock : Eine Untersuchung uber Wesen und Entstehung des Barockstils in Italien. Munchen: Theodor Ackermann,

ZANIN-YOST, A. - DONALDSON, Ch. 2005. "How to Speak Out (Visually) at Your Library" Library Philosophy and Practice (ejournal). 60. Available online: http://digitalcommons.unl.edu/libphilprac/60 
ZEMANEK, E. - NEBRIG, A. 2012. Komparatistik. Berlin: Akademie Verlag, 256 p. ISBN 978-3-05-005166-6.

Dr. Adriana Recka, PhD.

Faculty of Education

Constantine the Philosopher University

Tr. A. Hlinku 1

94901 Nitra

Slovakia

arecka@ukf.sk 